\title{
Democracy, Good Governance, and the Phenomenon of Corruption in Nigeria
}

\author{
J. Ademola Yakubu \\ Faculty of Law, University oflbadan,
}

\begin{abstract}
Democracy is a concept that has been recognized as an acceptable mode of governance. Embedded in this idea however are different approaches with respect to the attainment of this objective. The faults' inherent in some of these approaches led to the recognition of 'good governance' as a more acceptable concept in the description of the governance concept. Corruption is a negation of the ideals of democracy and good governance. This paper seeks to show how corruption has destroyed the fabric of 'democracy' and 'good governance' and the pursuit of the fundamental values of freedom, happiness, peace and order in the Nigerian society.
\end{abstract}

The focus of this paper is on democracy, good governance, and corruption. The first two of the three keywords are birds of the same feather or at least the first envisages the other. Corruption is a negation of the first two and incompatible with them. Since it cannot be denied that the phenomenon of corruption had in the past put an end to democracy and, to a large extent, good governance, the struggle for supremacy or superiority between the three key words cannot be determined by the use of two against one but by the effect on democracy and good governance.

Perhaps the starting is to explore their meanings. Democracy is a system by which the people through their elected representatives participate or form the government in accordance with laid down rules or principles. In law, democracy is a concept to be given shape in a carefully laid down or promulgated legal document which more often than not is regarded as the constitution. It should however be pointed out that this idea is well known by reason of practice and conventions that what ought to be done or how democracy should be practised may be regarded as conventions and may further be deducible from the Constitution or laws which are made by the body saddled with the responsibility of making laws, that is, the parliament, as the case in England. From a dynamic and practical consideration of this idea, democracy represents excellence in governance. A systematic way of government and governance, and an ingenious way of the whole people participating in government through their elected representatives. For example section 14(1) of the 1999 Constitution provides that "the Federal Republic of Nigeria shall be a state based on the principles of democracy and social justice". 
Good governance should be the primary objective of democracy. This is because one thing that differentiates democracy from other forms of government like fascism and autocracy is the possibility of participation in government through the elected representatives of the people and also through participatory consensus of the roleactors in governance; these role-actors being the representatives of the people. The argument whether good governance is an essential requirement of democracy or whether it is essential to it can be-tnet by the result which one achieves through democracy as opposed to other ideas like fascism or totalitarianism. Good governance is an objective of democracy. To say this without more is not be put an end to the other issue of whether good governance is the essence of democracy. In the context of this paper, the two expressions of essence and objective should be regarded as two sides of the same coin. An objective states the essence of an issue, so it matters not whether we argue that good governance is an essential_requirement of democracy or whether it is its objective as long as we agree that embedded in the idea of democracy is good governance. It could therefore be said that the goals of democracy Lead tcr good governance. For the purpose of coming to terms with this conclusion, the views of two eminent writers shall be put forward for the purpose of a clear elucidation of the nexus between democracy -and good governance. Mazrui identified four goals of democracy, which lead to good governance. According to him:

"The most fundamental of the goals of democracy are possibly four in number. Firstly, to make the rulers accountable and answerable for their actions and policies. Secondly, to make the citizens effective participants in choosing those rulers and in regulating their actions. Thirdly, to make the society as open and the economy as transparent as possible; and fourthly to make the social order fundamentally just and equitable to the greatest number possible. Accountable rulers, actively participating citizens, an open society and social justice: those are the four fundamental ends of democracy". ${ }^{1}$

Nwabueze in his discourse on the relationship between good governance and democracy gave three values or principles of good governance, which must be found in any discussion on democracy as they are essentials of democracy. Thus, it could be said that good governance is part of democracy although not the totality of what democracy stands for. The three values or principles of good governance given by Nwabueze are:

(i) Guaranteed democratic rights and freedoms, i.e. rights without which there can be no effective popular control of

1 All A. Mazrui, "Who killed Democracy in Africa? Clues of the Past, concerns of the Future" in Democracy, Development 'and Poverty: The Debate and the struggle continues. Development Policy Management in SubiSaharan Africa Volume IX, Number 1, February 20Q2 pg. 15. 
public decision making processes and therefore no meaningful democracy, rights like a guaranteed right of citizens to meet and associate together for political purpose (not necessarily as a political party), to express themselves on public affairs, to have access to information, to seek to persuade others, to move about freely in order to exercise their democratic rights;

(ii) The rule of law with its various elements - the protection of individual rights, the guarantee of fair trial and due process of law, the subjection of state officials to the law - as well as the institutions and devices necessary for its effective and meaningful operation, like the separation of powers between the legislative assembly, executive and judiciary;

(iii) Justice, with its adjunct equality - both equality before the law and equal treatment of citizens by the state - is a principle so inextricably linked with liberty and the rule of law that true democracy cannot exist without it". ${ }^{2}$

The restrictive definition of good governance, which Nwabueze gave as being essential requirements of democracy, is consistent with his view that good governance is not necessarily the essence of democracy. This view cannot!be accepted because the word "good" emphasizes that which conforms to the general order or that which advances the welfare of persons or that which is beneficial. To say as Nwabueze said that "the other elements of good governance - security, happiness, the good life etc. all of which can be subsumed under the rubric of the public good or the welfare of the people - are clearly not essential requirements of democracy; they do not pertain to its essence" would seem to take a very restrictive view of good governance and to negate the meaning of the word "good". But Nwabueze said in another context "an essential requirement of democracy is something necessarily implied in its definition, something integral, not external, to it, and therefore pertains to its essence, for example, is the concept of accountability". ${ }^{3}$ Nwabueze said further, democracy cannot adequately or accurately be defined without reference to the accountability of the rulers to the ruled any more than can it be defined without reference to the principle of popular control of the decisionmaking processes of government, exercised through such devices and institutions as free and fair elections at periodic intervals of time, representative governmental bodies, free speech, public assemblies and processions etc". ${ }^{4}$ To the extent that Nwabueze did not close the categories of issues that come under his definition of democracy, and to the extent that the category of issues

\footnotetext{
2 Professor Ben Nwabueze, SAN, "Budgeting for Good Governance and Constitutional Responsibilities, Nigerian Tribune, No. 13,047, Tuesday 11 February 2003

${ }^{3}$ Tribune, op cit, first column, back page (page 40)

${ }^{4}$ Prof. Nwabueze, ibid, page 40.
} 
mentioned under democracy are not inconsistent with the plain meaning of democracy, it can be concluded that the restrictive definition given to good governance by Nwabueze should be enlarged to bring in those issues recognised by Mazrui and also contained in his definition of democracy. This conclusion may lead to another issue. The issue is, is good governance not another name for democracy? Is it not that the expression "democracy" was coined a long time ago and it has now been given a twin definition "good governance"? Or is it not that one, i.e. democracy is a vogue word whereas good governance is yet to be the vogue for what democracy tries to achieve but which is embedded in good governance? Must the definition of democracy continue to rest on the simple definition of "government of the people by the people and for the people"? Is it not more inclusive to define democracy as an art of good governance through the observance of basic principles and tenets that give rise to a just and egalitarian society? As pointed out above good governance should be the new definition of democracy and bad governance should be the new name for fascism or totalitarianism.

Now that it has been resolved that there is no incompatibility between democracy and good governance, the next issue to consider is how far we have been able to,come to terms with democracy or good governance through the composite document which the Constitution represents, for it is within this context that democracy or good governance can be discussed. In any event, the 1999 constitution like its precursors, states in section 1(1) that:

"This constitution is Supreme and its provisions shall have binding force on all authorities and persons throughout the Federal Republic of Nigeria".

Subsection (3) to section 1 states that:

"If any other law is inconsistent with the provisions of this constitution, this constitution shall prevail, and that other law shall to the extent of the inconsistency be void".

\footnotetext{
${ }^{5}$ Abraham Lincoln's Gettysburg Speech. See also, J. Ademola Yakubu (ed.) Kayode Eso, Further Thoughts on Law and Jurisprudence, Spectrum 2003 pg. 105. Nwabueze noted that "the government of the people by the people for the people " is explicitly affirmed as a guiding principle of the democratic state established by the transition constitutions of 14. Francophone African countries, re-enacting ah identical provision in the Independence Constitutions of 11 of them -Alge'ria 1996 Constitution, Articles 1 and 11; Republic of Benin 1990, Article 2 (as in 1959); Chad 1996, Articles 1 and 7; Congo (Brazaville) 1992, Articles 1 and 4 (as to multiparty democracy in 1990..1994 and 1998); Djibouti 1992, Article 1; Gabon 1995, Article 2 (as in 1964); Guinea 1990, Article 1 (as in 1964); Nigeria 1996, Article 4 (as in 1960); Rwanda 1992, Articles 1 and 2 (as in 1960); Burkina Faso (as in 1960) though not in 1991 Constitution”. See B. Nwabueze, Nigerian Tribune op. cit. pg. 26.
} 
What is more, section 2 of the 1999 Constitution states the basis of governance through the 1999 Constitution. It states that:

"The Federal Republic of Nigeria shall not be governed, nor shall any person or group of persons take control of the Government of Nigeria or any part thereof, except in accordance with the provisions of this constitution".

The various heads earlier identified will be used for the purpose of gauging the observance of the tenets of democracy or the requirements of good governance.

\section{Accountability}

Accountability is not limited to its commercial meaning but the requirement that the officials of government are answerable to the people in terms of their actions. As such, it relates to overt acts of officials in line with the requirements of governance as dictated by the Constitution and their conscience and also with respect to the management of funds that have been put in their care for the purpose of governance. Section 2 of the 1999 Constitution provides that governance must be in accordance with the provisions of the Constitution. Thus, the basis of any person's participation in government is the Constitution and such participant in government is accountable to the people according to the demands of the Constitution. Section 13 of the 1999 Constitution, which though is under Fundamental Objectives and Directive Principles of State Policy states that:

'It shall be the duty and responsibility of all organs of government, and of all authorities and persons, exercising legislative, executive or judicial powers, to conform to, observe and apply the provisions of this chapter of this constitution".

The issue of accountability has been emphasised by section 14(1) of the 1999 Constitution. It states that:

"The Federal Republic of Nigeria shall be a state based on the principles of democracy and social justice".

Section 14(2) of this constitution further provides that:

"It is hereby, accordingly declared that -

(a) Sovereignty belongs to the people of Nigeria from whom government through this constitution derives all its powers and authority; 
(b) The security and welfare of the people and the primary purpose of government; and

(c) the participation by the people in their government shall be ensured in accordance with the provisions of this constitution". ${ }^{6}$

Since the ultimate power resides in the people and their wish with respect to governance on various issues can be determined from the constitution, the elected representatives must account to the people, who are the ultimate owners of the power in accordanpe with required procedure and tenets as stipulated in the Constitution. The meaning of what is being said will be better appreciated if it-is explained through its non-observance. In Lakanmi v Attorney General West, ${ }^{7}$ following the intervention of the military in January 1966, Decree No. 1 of 1966 was promulgated. This decree suspended some sections of the 1963 Constitution. It modified some others. The section of that Constitution which stated that it was supreme was suspended. By virtue of Edict No. 5 of 1967, the property of Lakanmi and some others was confisticated. The High Court gave effect to the Edict of the state government. 'The Federal Military Government passed three successive Decrees for the! purpose of validating the action of the Western State government. The consequence was the striking out of the appeal of the appellants. On further appeal to the Supreme Court, the learned Attorney General for the Western State, on behalf of the respondents maintained that the military was not accountable to anybodjy. In his words: "What took place in January 1966 was a revolution". He argued further that the Federal Military Government was a revolutionary Government, which seized power on 15 January 1966 and that it accordingly had an unfettered right from the start to rule by force and by means of Decrees and also that nothing from the Republican Constitution of 1963 can be implied into the new mode of ruling the country. By this argument, the learned Attorney General stated that the military was not accountable to any body. A government that cannot be checked by any law except in accordance with its own prescription, not according to standard rules but by the whims of its prescription, cannot be regarded as democratic and although it may govern, it is doubtful whether by such method it can pass the test of good

\footnotetext{
${ }^{6}$ Notwithstanding that all the sections quoted above, that is sections Q, and 14 afe under Fundamental Objectives and Directive Principles of State Policy and they are not justiciable by virtue of Section 6(6)(c), they are important and provisions akin to those contained in chapter II can be found in the constitutions of many countries including India. See also Article 36 of the Constitution of Ghana 1992 and Article 215 of the Constitution of the Gambia 1996. Though contained under the chapter titled "Fundamental Objectives and Directive Principles of State Policy" they provide that "the-most secure democracy is the one that assures the basic necessities of life for Us people as a fundamental duty" and the said objectives emphasise security of "maximum welfare, freedom and happiness of every person". Ten other countries that have followed the embodiment of "Fundamental Objectives and Directive Principles of State Policy" are Zambia (1991); Uganda (1995); Tanzania (1984) as amended in 1992; Malawi (1992) as revised in 1994 and 199.5; Lesotho (1991) and (1996) and Eritrea (1997). See Prof. Ben Nwabueze, “Budgeting for Good Governance and Constitutional Responsibilities” Nigerian Tribune, Tuesday 11 February 2003 at pg: 26
}

${ }^{7}[1971] 1$ U.I.L.R. 201 
governance. ${ }^{8}$ Chief F.R.A. Williams apparently had democracy or good governance in mind when he put forward his defence. According to him, the Federal Military Government was not a revolutionary government but a constitutional interim government, which came into being by the wishes of the representatives of the people, and whose objective was to uphold the Constitution, excepting so far as it had to derogate from it under the doctrine of necessity whereby it was granted power. He further argued that the Federal Military Government assumed the continued, existence of the Constitution and in its Decree No. 1 of 1966 impliedly provided for a separation of powers between the legislature, the* executive and the judiciary as did the Constitution of Nigeria; that this must be perpetuated unless necessity otherwise arose compelling it under section 3 of Decree No. 1 of 1966 to make laws by Decree "for the peace, order and good government of Nigeria on any matter whatsoever". The argument of Chief F.R.A. Williams was an argument for democracy and good governance. Despite the fact the Supreme Court allowed the appeal and declared Edict No. 5 of 1967 and Decree No. 45 of 1968 ultra vires, null and void, the Military Government passed Decree No. 28 (Supremacy and Enforcement of Powers) Decree No. 1970 for the purpose of overriding the decision of the Supreme Court. The action of the Federal Military Government showed that it was not accountable to anybody not even the rule of law, which bestowed and still bestows on the courts the power to declare the rights and privileges of persons. The Supreme Court of Australia had the accountability of the government to the people in mind when it held in Attorney General of Australia v The Queen ${ }^{9}$

"Those who wrote our constitution well knew the danger inherent in special legislative acts which take away the life, liberty, or property of particular named persons, because the legislature thinks them guilty of conduct which deserves punishment. They intended to safeguard the people of this country from punishment without trial by duly constituted courts."

The court made the same point in Re Mohammed Olayori \& ors "' when it held that:

"... if we are to live by the rule of law, if we are to have our actions guided and restrained in certain ' ways for the benefit of the society in general and individual members in particular, then whatever status, whatever post we hold we must succumb to

\footnotetext{
${ }^{8}$ A military government, at least in the context of Nigeria, is usually referred to as a corrective government in order to save the country from disintegration. To this extent, the intervention of the m'ilitary may be welcome, but whenever the period of necessity passes, it should return the government to a democratically elected one otherwise the military may earn a negative appellation.

${ }^{9}$ [1957] AC 288

${ }^{10}$ Suit No. M/196V69
} 
the rule of law. The alternative is anarchy and chaos..."

Accountability in a way requires submission of one's action, be it legislative or executive, to public scrutiny. It requires the possibility of making the action the subject of litigation by a court or other tribunal established by law and constituted in such a manner that secures its independence and impartiality. Even where a court or a tribunal has been constituted in such a way that its impartiality cannot be asserted, it is for the judicial institution, to caution itself through its own self cautioning and self review system as could be found in the idea of judicial precedent and other concepts and principles of law such as preliminary objection idea and other similar ones.

In a democratic system, an elected representative of the people no matter how powerful, or is it popular cannot declare, "I am the state". Should an elected representative behave above the law or should he feel he is not accountable to the people, he can be removed or recalled. For example, section 143 of the 1999 Constitution provides that the President can be removed from office on account of "gross misconduct". The same goes for the governor under section 188 of the 1999 Constitution.

With respect to financial accountability, various sections of the Constitution call for financial accountability on the part of functionaries of government. On order to ensure this, various sections of the 1999 Constitution make it imperative for public functionaries to declare their assets and liabilities. For example, section 140(1) of the 1999 Constitution provides that:

"A person elected to the office of Presidentshall not begin to perform the functions of that office until he has declared his assets and liabilities as prescribed in this constitution and he has taken and subscribed the oath of Allegiance and the oath of office prescribed in the Seventh Schedule to this Constitution."

Accountability of elected representatives and indeed all functionaries of government is a sine qua non for democracy to thrive or for good governance to hold sway.

\section{Choice of Rulers}

Election is the most acclaimed method of choosing rulers. These rulers, in a democratic set up or where good governance is envisaged are meant to be the representatives of their electors. The Constitution provides for how people can be elected to different elective offices. Election to various

\footnotetext{
${ }^{11}$ See also Section 185 of the 1999 Constitution
} 
offices is through political parties. One problem that the political parties of the past from the period of independence up till 1999 had was formation of political parties along ethnic lines. ${ }^{12}$ In a federal set up like the case of Nigeria, the best that can be achieved through the electoral process rather than parochial consideration should be emphasised.

As Beetham put it:

"From the standpoint of popular control, elections exert an effect well beyond the time when they are actually taking place. This is due to the well-known law of anticipated reactions; power is operative even when it is not being exercised. The fact of the vote casts a long shadow in front of it, as it were. It acts as a continuous discipline to the elected, requiring them to give public account of their actions and to take constant notice of public opinion through its various cannels of expression - media comment, opinion polls, party meetings, lobbying activity and so on. In the economy of political time, voting delivers a considerable degree of control for a small outlay, to an extent that is liable to be overlooked if we concentrate on the act alone and ignore all that it causes to happen". ${ }^{13}$

As stated above, for the purpose of realising the democratic objective or good governance various qualifications are provided for those aspiring to these various posts. For example, section 65 of the 1999 Constitution provides for qualifications for election as a member of the National Assembly. Sections 58 and 59 of the 1999 Constitution provide for the mode of exercising federal legislative power. Sections 133 - 134 provide for election to the office of the President. Section 142 deals with election to the office of the Vice-President. Sections 177-179 of the 1999 Constitution deal with election to the office of the governor of a state. Section 187 of the 1999 Constitution deals with election to the office of deputy governor. These persons must perform their duties according to law. That no elected representative of the people is above the law can be seen from section 2 of the 1999 Constitution, which provides that:

"The Federal Republic of Nigeria shall not be governed, nor shall any person or group of persons take control of the Government of Nigeria or any part thereof, except in accordance with the provisions of this constitution".

\footnotetext{
${ }^{12}$ see J.J. Oluleye, Military Leadership in Nigeria 1966 - 1979.

${ }^{13}$ David Beetham, quoted by B. Nwabueze in Tribune, op. cit. pg. 26.
} 
Furthermore, sections 4 and 5 provide for the methods of legislating and of executing laws by the legislature and the executive respectively. Section 6 of the 1999 Constitution provides for judicial powers. Section 6(6) of the 1999 Constitution provides that:

"The judicial powers vested in accordance with the foregoing provisions of this section

(a) shall extend, notwithstanding anything to the contrary in this constitution, to .all inherent powers and sanctions of a court of law;

(b) shall extend to all matters between persons, or between government or authority and to any person in Nigeria and to all actions and proceedings relating thereto, for the determination of any question as to the civil rights and obligations of that person".

It must however be stated that issues relating to the observance and fulfilment of the Fundamental Objectives and Directive Principles of State Policy set out in Chapter II of the 1999 Constitution, as it was the case under the 1979 Constitution, cannot be made justiciable issues in the court of law except so far as those issues have left the province of Fundamental Objectives and Directive Principles and have thus become justiciable issues. Furthermore, by virtue of section 308 of the 1999 Constitution, a person holding the office of President or Vice-President, Governor or Deputy Governor cannot be proceeded against in respect of their acts or omissions both in respect of civil or criminal proceedings. The language of section 308 of the 1999 Constitution goes thus:

"308(1) Notwithstanding anything to the contrary in this constitution, but subject to subsection (2) of this section-

(a) no civil or criminal proceedings shall be instituted or continued against a person to whom this section applies during his period of office;

(b) a person to whom this section applies shall not be arrested or imprisoned during that period either in pursuance of the process of any court or otherwise; and

(c) no process of any court requiring or compelling the appearance of a person to whom this section applies, shall be applied for or issued: 
Provided that in ascertaining whether any period of limitation has expired for the . purpose of any proceedings against a person to whom this section applies, no account shall be taken of his period of office.

(2) The provisions of subsection (1) of this section shall not apply to civil proceedings against a person to whom this section applies in his official capacity or to civil or criminal proceedings in which such a person is only a nominal party.

(3) This section applies to a person holding' the office of President or Vice-President, Governor or Deputy Governor; and the reference in this section to "period of office" is a reference to the period during which the person holding such office is required to perform the functions of the office"

One further point that must be made is that apart from the elected representatives of the people who are otherwise regarded as the rulers and who are subject to the laws of the land as authoritatively pronounced by the Constitution and other laws made by constituted authorities, there are also civil servants and other public servants who give effect to the activities of the operators of the three tiers of government. They also act or perform their duties in accordance with law.

An Open Society and Transparent Economy Democracy or good governance thrives where the society is open. An open society is that which ensures that governmental activities are carried out in an open manner or in accordance with laid down rules or procedure. It enables citizens to contribute to governance through suggestions or advice and it is not opposed to constructive criticisms or censorship as and when necessary. It is a society that ensures open trial and vindication of grievance's without fear or favour. An open society ensures freedom of speech and of the press. Issues relating to open society are to be found in the 1999 Constitution. For example, section 34 of the 1999 Constitution provides that every individual is entitled to respect for the dignity of his person, and accordingly no person shall be subjected to torture or to inhuman or degrading treatment and no person shall be held in slavery or servitude. Section 35 of the 1999 Constitution provides that every person shall be entitled to his personal liberty and no person shall be deprived of such liberty except as permitted by law. Section 37 ensures the protection of privacy of citizens, their homes," correspondence, telephone conversations and telegraphic communication. Section 38 of the 1999 Constitution assures right to 
freedom of thought, conscience and religion. Section 39 of this Constitution assures right to freedom of expression and the press. Section 39(1) states that every person shall be entitled to freedom of expression, including freedom to hold opinions and to receive and import ideas and information without interference. An open society also assures right to peaceful assembly and association. This is guaranteed by section 40 of the 1999 Constitution. The right to freedom of movement, which is to be found in section 41 of the 1999 Constitution, is a vital right that can only be found in an open society. A society that is free from discrimination is an open society. Section 42 of the 1999 Constitution assures this. What is more, section 36(1) of the 1999 Constitution assures access to court when it provides thus:

"In the deterrnination of his civil rights and obligations, including any question or determination by or against any government or authority, a person shall be entitled to a fair hearing within a reasonable time by a court or other tribunal established by law and constituted in such manner as to secure its independence and impartiality".

Section 36(4) assures openness of trials in all cases except in the interest of defence, public safety, public order, public morality, and public interest ${ }^{14}$ or on account of the age of any of or the parties involved. It states in general terms thus:

Whenever any person is charged with a criminal offence, he shall, unless the charge is withdrawn, be entitled to a fair hearing in public within a reasonable time by a court or tribunal".

Yacob J. summarily underscored the tenets of an open society when he held in The Government of the Republic of South Africa \& ors $v$ Grootboom \& ors ${ }^{15}$ thus:

"Our constitution entrenches both civil and political rights and social and economic rights. All the rights in our Bill of rights are inter-related and mutually supporting. There can be no doubt that human dignity, freedom and equality, the foundational values of our society, are denied those who have no food, clothing or shelter. Affording socio-economic rights to all people therefore enables them to enjoy the other rights enshrined in chapter 2 . The realisation of these rights is also the key to the advancement of race and gender equality and the

\footnotetext{
${ }^{14}$ See also Section 45 of the 1999 Constitution. ${ }^{\text {I5 }}$ [2001]6WRN 137
} 
evolution of a society in which men and women are equally able to achieve their full potential".

With respect to transparent economy, it should be stated that a transparent economy is a sine qua non for democracy to thrive or for good governance to predominate. A corrupt economy is a negation of democracy for such a government cannot be the government of the people. The people cannot elect their representatives in order to put in place a corrupt economy and thus pauperise them. It is a negation of the social contract, which serves as the basis for the institution of government and for the resolution to regard the elected by the electors as their representatives for the purpose of ensuring the smooth running of government. That transparent economy is the desire of the government of Nigeria can be determined from section 15(5) of the 1999 Constitution, which provides that "the state shall abolish all corrupt praptices and abuse of power". Furthermore, section 16(1) of the 1999 Constitution provides that:

"The state shall, within the context of the ideals and objectives for which provisions are made in this constitution -

(a) harness the resources of the nation and promote national prosperity and an efficient, a dynamic and self- reliant economy;

(b) control the national economy in such manner as to secure the maximum welfare, freedom and happiness of every citizen on the basis of social justice and equality of status and opportunity".

Section 16(2) further provides that:

"The state shall direct its policy towards ensuring -

(a) the promotion of a planned and balanced economic development;

(b) that the material resources of the nation are harnessed and distributed as best as possible to serve the common good;

(c) that the economic system is not operated in such a manner as to permit the concentration of wealth or the means of production and exchange in the hands of few individuals or of a group; and

(d) that suitable and adequate food, reasonable national minimum living wage, old age care and pensions and unemployment, sick benefits and welfare of the disabled are provided for all citizens". 
Furthermore, section 17(d) of the 1999 Constitution provides that the "exploitation of human and natural resources in any form whatsoever for reasons, other than the good of the community, shall be prevented".

The effect of all these provisions of the 1999 Constitution is that transparent economy is a requirement in the governance of Nigeria. For example the Independent Corrupt Practices Commission was set up by the Act of the National Assembly to combat corruption and ensure transparent economy. ${ }^{16}$

\section{Social Justice and the Rule of Law}

Nigeria is presumably founded on social justice or rule of law. The preamble to the 1999 Constitution states in part that the constitution has been put in place "for the purpose of promoting the good government and welfare of all persons in our country on the principles of freedom, equality and justice, and for the purpose of consolidating the unity of our people".

Section 14(1) of the 1999 Constitution also provides that "the Federal Republic of Nigeria shall be a state based on the principles of democracy and social justice". In furtherance of this, section 14(2) of the 1999 Constitution provides that:

"It is hereby, accordingly, declared that -

(a) Sovereignty belongs to the people of Nigeria from whom government through this constitution derives all its powers and authority;

(b) The security and welfare of the people shall be the primary purpose of government; and

(c) The participation by the people in their government shall be ensured in accordance with the provisions of this constitution.

Section 17 of the 1999 Constitution is a summation of what democracy or good governance requires. It adequately describes the essence of social justice and rule of law. It provides thus:

"17(1) The state social order is founded on ideals of Freedom. Equality and Justice.

(2) In furtherance of the social order -

\footnotetext{
${ }^{16}$ See the Cnrctm Practices and Other Related Offences Act. 2000
} 
(f) children, young persons and the aged are protected against any exploitation whatsoever, and against moral and material neglect;

(g) provision is made for public assistance in deserving cases or other conditions of need; and

(h) the evolution and promotion of family life is encouraged".

The question that easily arises is that all the issues mentioned under this heading, except the preamble are to be found in Chapter II of the 1999 Constitution which deals with Fundamental Objectives and Directive Principles of State Policy which are not justiciable. It should however be stated that all the issues contained in sections 14 and 17 of the 1999 Constitution which form part of Chapter II of the 1999 Constitution are eloquent, more elaborate and systematic way of putting together the various fundamental human rights provisions in Chapter IV of the 1999 Constitution as well as sections 4, 5 and 6 of the 1999 Constitution. With respect to section 4 of the 1999 Constitution, there are various sub-sections of this section dealing with these issues. In any event, is anything more embracing than section 4(2) of the 1999 Constitution which allows the National Assembly to make laws for the peace, order and good government of the Federation or any part thereof not only with respect to the issues contained in the Exclusive and concurrent Legislative lists but also with respect to any other matter with respect to which its is empowered to make laws in accordance with the provisions of this constitution? Section 4(7) also empowers the state to do the same. With respect to the executive, section 5(1) of the 1999 Constitution vests in the President executive powers which said power shall, by virtue of section $5(1)(\mathrm{b})$ "extend to the execution and maintenance of this Constitution, all laws made by the National Assembly and to all matters with respect to which the National Assembly has, for the time being, power to make laws". The State governor has also been so empowered by virtue of section 5(2) of the 1999 Constitution within the limit of the power of the House of Assembly of the State. Furthermore, social justice and rule of law are assured concepts in Nigeria and consequently democracy can thrive and good governance can be asserted by virtue of section 6 of the 1999 Constitution. In line with the recognition of the national government and the State government, section 6(1) opens the judicial powers bestowed on the courts when it provides that "the judicial powers of the Federation shall be vested in the courts to which this section relates, being courts established for the Federation". Section 6(2) complements this when it provides that "the judicial powers of a state shall be vested in the courts to which this section relates, being court; 
(a) every citizen shall have equality of rights, obligations and opportunities before the law;

(b) the sanctity of the human person shall be recognised and human dignity shall be maintained and enhanced;

(c) governmental actions shall be humane;

(d) exploitation of human or natural resources in any form whatsoever for reasons, other than the good of the community, shall be prevented; and

(e) the independence, impartiality and integrity of courts of law, and easy accessibility thereto shall be secured and maintained

Section 17(3) further assures social justice and the rule of law. It provides thus:

"The State shall direct its policy towards ensuring that-

(a) all citizens, without discrimination on any group whatsoever, have the opportunity for securing adequate means of livelihood as well as adequate opportunity to secure suitable employment;

(b) conditions of work are just and humane, and that there are adequate facilities for leisure and for social, religious and cultural life;

(c) the health, safety and welfare of all persons in employment are safeguarded and not endangered or abused;

(d) there are adequate medical and health facilities for all persons;

(e) there is equal pay for equal work without discrimination on account of sex, or on any other ground whatsoever; 
established, subject as provided by this constitution, for a State. Furthermore, section 6(6) of the 1999 Constitution provides that:

"6(6) the judicial powers vested in accordance with the foregoing provisions of this section -

(a) shall extend, notwithstanding anything to the contrary in this constitution, to all inherent powers and sanctions of a court of law;

(b) shall extend to all matters between persons, or between government or authority and to any person in Nigeria, and to all actions and proceedings relating thereto, for the determination of any question as to the civil rights and obligations of that person".

The court itself cannot invite litigants. The court cannot suo moto and in the scheme of things, initiate civil and criminal actions. Litigation must be commenced by litigants. Section 36(1) of the 1999 Constitution provides necessary access in this regard. It states that:

"In the determination of his civil rights and obligations, including any question or determination by or against any government or authority, a person shall be entitled to a fair hearing within a reasonable time by a court or other tribunal established by law and constituted in such manner as to secure Its independence and impartiality".

The good thing about section 6 is that the judiciary is recognised as the institution given the power to decide disputes between persons and between persons and the government or any part of it. Access to that institution makes for grievance remedial technique with less rancour or discontent. The courts maintain the standard tenets of justice as recognised by the Constitution and other enabling laws. The lawyers, who are the ministers in the temple of justice, serve as deserving ministers in this respect and the litigants are the recipients of these standards, which end in justice being done. Justification for peace in the society is based on these /standards. Plamentaz made the point when he said that:

"Men and women are supposed to be strongly attached to standards accepted by them all that dispute seldom arise between them, and if they do, are quickly and easily settled by methods that everyone agrees are just. If a settlement goes against 
a man, he may regret it but he does not feel aggrieved; he believes that justice has been done". ${ }^{17}$

With respect to all the issues stated above, two concepts of law act as the pillars upon which they are based. These concepts are rule of law and separation powers. What is rule of law? What is separation of powers? Perhaps we should start with the rule of law. Aristotle, the Greek philosopher stated in his book on politics, ${ }^{18}$ around 2,000 B.C. that the rule law was preferable to that of an individual. Bracton, a $13^{*}$ century $^{19}$ jurist opined that the world was governed by law, either human or divine and that the king himself might not be subject to man but "he is surely subject to God and the law because it is the law that makes him king". Coke took this idea to represent a "golden and strait met wand of law as opposed to the uncertain and crooked cord of discretion". ${ }^{20}$ The summary of it is as given by the Supreme Court in Military Governor of Lagos State \& ors $v$ Chief Emeka Odumegwu Ojukwu. ${ }^{21}$

The Supreme Court held thus:

"The Nigerian Constitution is founded on the rule of law the primary meaning of which is that everything must be done according to law. It means also that government should be conducted within the framework of recognised rules and principles which restrict discretionary power".

Interestingly, the 1999 Constitution provides the meaning that should be ascribed to the rule of law. It states in section 1(2) that:

"The Federal Republic of Nigeria shall not be governed, nor shall any person or group of persons take control of the Government of Nigeria or any part thereof, except in accordance with the provisions of this Constitution".

With respect to separation of powers, Montesquieu, the French jurist gave us an idea of it. He said:

"Political liberty is to be found only when there is no abuse of power. But constant experience shows us that everyman invested with power is liable to abuse it, and to carry his authority as far as it will go... To prevent this abuse, it is necessary from the

\footnotetext{
${ }^{17}$ Ptamenatz John, Karl Marx's Philosophy of Man (Clarendon Press, Oxford, 1975) pg. 396.

${ }^{18}$ Aristotle Politics Vol. Ill page 16.

${ }^{19}$ Bracton, De Legibus et Consetudinibus Angliae, 5. 5b

${ }^{20}$ Coke, 4Instl. 41.

${ }^{21}$ [1986] All NLR 233
} 
nature of things that one power should be a check on another... when the legislative and executive powers are united in the same person or body... there can be no liberty if the judicial power is not separated from the legislative and executive. There would be an end to everything if the same person or body, whether of the nobles or of the people, were to exercise all these powers". ${ }^{22}$

Salami JCA was also of the same frame of mind when he held in Hononrable Abdullahi Maccido Ahmad v Sokoto State House of Assembly \& anor" that:

"The organic structure created by Part II of Chapter 1 of both constitutions of the Federal Republic of Nigeria, 1979 and 1999 are three organs of power of the Federal Republic of Nigeria. Of these powers, legislative powers are vested in the legislature at both federal and state levels; the executive i.e. President at the Federal and the Governor at the State level. Judicial powers both at the Federal and State levels are vested in the courts established fof the Federation and the States under section 6 of the Constitution..." 24

Salami JCA speaking further in Ahmad v Sokoto State House of Assembly anor with respect to failure of the lower court to assert its authority as an arm in the tripartite classification of powers said:

"The learned trial Chief Judge... capitulated when she declined jurisdiction. The implication of her meekly and without resistance readily surrendering judicial power has the effect of demolishing the edifice of doctrine of separation of powers; a doctrine that has taken long toiling hours to erect by our past heroes. It seems to me respectfully that she by that single act dealt a deadly blow at the "labour of our heroes past" and rendered them in vain, Even in cases of ouster clauses, the courts have always struggled to maintain and guard their sovereignty in the determination of civil rights and obligations of the citizen of this country". ${ }^{25}$

\footnotetext{
${ }^{22}$ Montesquieu

${ }^{23}$ [2002] 44 WRN 52

24 at pg. 69

25 at pg. 70
} 
We can now proceed to examine the phenomenon of corruption in governance.

\section{Corruption}

Corruption is the antithesis of democracy. It is the opposite of everything that makes for good governance. Corruption is one word that is known to all and sundry. Just as in the case of democracy and good governance, the word corruption which is all encompassing is usually, in ordinary parlance, taken to be different from 'bribery', hence the usual tag of "bribery and corruption". It is submitted that bribery is part of the allencompassing definition or description of that negative attitude to governance and performance of public responsibility or duty called corruption. Therefore in a discourse that has democracy or good governance as its theme, the addition of corruption is a discussion of opposing issues in the same context. ${ }^{26}$ However, since these opposing issues are facts of life and exist in our society by reason of the nature of man and complexity of the society or negative development in governance, it would be begging the issue to look at corruption and democracy or good governance only cursorily by reason of one being the antithesis of the other.

The first hurdle is giving an acceptable definition to the word "corruption". Corruption suffers from the well-known problem of ascribing an all-encompassing meaning to a term that serves as the theme of that discourse. ${ }^{27}$ Notwithstanding this however, corruption can simply be defined as "an inducement by means of an improper consideration to violate some duty" ${ }^{28}$ Corruption is a social problem; the nature of it and the extent to which it has permeated a particular society must be determined in the context of that particular society. Notwithstanding this conclusion, it could be said that in all societies where corruption has become their bane, it manifests itself in the nature of fraud, gratification, use of office for pecuniary advantage, influence peddling, underserved pay, tardiness and slovenliness. ${ }^{29}$ Honourable Justice Eso noted the impact of corruption on a

\footnotetext{
${ }^{26}$ See J. Ademola Yakubu, "Corruption and Democracy", text of the paper delivered at the National Workshop on the Anti Corruption Act, Faculty of Law, Olabisi Onabanjo University, Ago-lwoye, between May 15 and 16, 2002. See also J. Ademola Yakubu, "White Collar Criminality -Corruption with reference to Corporate Organisations in Nigeria.

${ }^{27}$ Ayoade M.A., 'Eradication of Corruption and other Economic Crimes within the Administration of Justice" - Problems and Prospects, in Perspectives on Corruption and other Economic Crimes, ed Kalu U. Ama \& Osinbajo Yemi, 1991 pg. 213.

${ }^{28}$ L B. Curzon, A dictionary of Law, Macdonald and Evans. See also Prof. M.O. Adeniran "Legal and Institutional Mechanisms Against Corruption in Nigeria" - Problems «/ 'Corruption in Nigeria ed. 1.A. Ayu, SAN and B. Owasanoye pg. 321. Other descriptive definitions include: Perkins \& Boyce "impunity or debasement and when found in the criminal statute it means depravity or gross impropriety"

${ }^{29}$ Address of Professor Afolabi Soyode, Vice Chancellor, Olabisi Onabanjo University, Ago-Iwoye at the National Workshop on the Anti-Cofruption Act, 2002, organised by the Faculty of Law, Olabisi Onabanjo University, Ago-lwoye between May 15 and 16, 2002 pg. 2. See also Y.
} 
nation and its economy while submitting the report of his panel on corruption thus:

"Whenever and wherever this phenomenon occurs, its effects tend to damage the accepted goals of public order, good government and national development quite seriously. On nations, new and old, the impacts of massive corruption and associated crimes have been such as to evoke public outcries and calls for timely remedial action". ${ }^{30}$

\section{Corruption in Nigeria}

The geographical expression now known as Nigeria was an expression of many settlements inhabited by people of diverse cultural affiliations, values, and social systems including judicial. ${ }^{31}$ The advent of the British and the subsequent colonisation of Nigeria by the British led to the transplantation of British values and systems on the soils of these diverse settlements. By 1914, the British had succeeded in bringing these various settlements together under a name called Nigeria. The Affect of this development was the gradual subjugation of the traditional values and ethos. The traditional values and ethos were opposed to impurity and debasement, which are the attributes of the definition of the word "corruption". The rule it was in these various settlements that anything relating to impurity and debasement called for appropriate punishments. With the introduction of the British or western values and civilisation came a change in the economy. The economy became a monitised economy. It took a complex dimension. Rulership or governance together with the appertaining institutions became diverse. The western civilisation realised the evils that the complex system might bring having regard to the experience of the colonial overlord in other territories and within its own system in the country of origin. As far back as 1945, the Criminal Code had put in a written order an offence called corruption in some of its ramifications. The Penal Code followed suit in 1959. Upon Independence in 1960, the Criminal Code and the Penal Code continued to regulate criminal activities including those relating to corruption. The nationalists, at independence, became the rulers together with other indigenous elites. The struggle for political relevance and economic opulence led to their desire to

\footnotetext{
Akinseye-George in Legal System Corruption and Governance in Nigeria, New Century Publishers Ltd. 2000. ${ }^{30}$ Address of Honourable Justice Kayode Eso on the occasion of the presentation of the National Committee on Corruption and other Economic Crimes, in Perspectives on Corruption and other Economic Crimes in Nigeria, ed. Kalu \& Osinbanjo pg. 245.

${ }^{31}$ See J. Ademola Yakubu, "The Role of African Intermediaries in the Colonial Adjudicatory System in the Native Courts in Nigeria", paper presented at African studies centre, University of Stanford, California, USA, (2002) J. Ademola Yakubu, "Colonialism, Customary Law and Post Colonial State in Africa: The case of Nigeria", paper presented at $10^{\text {th }}$ General Assembly of Codesria, Kampala, Uganda (2002).
} 
amass wealth in disgusting proportion. The orchestrated independence became a notional value as the sovereignty it brought became marred by selfish desires of some of the erstwhile nationalists who had the opportunity of becoming the first rulers of the people. At independence, the society put in place by the colonialists was not an egalitarian state. It was a capitalist state that began to produce its petit bourgeoisie and also led to the rising of crime rate and criminal intents on the part of the citizens who became disillusioned by the nature of the state that began to develop after independence. Odekunle put the nature of the Nigerian society that began to emerge in brilliant terms when he said:

"Having created the desires, aspirations and expectations for wealth, property, power and prestige in everybody, it fails (because it is inherently unable) to guarantee or ensure the equitable distribution of the means and opportunities to meet the created desires, aspirations and expectations as well as provide effective checks and balances and therefore minimise, if not avoid, the "corrupting privileges" of the such, the "corrupting deprivators" of the poor and the crime - problem that is largely a function of both. Because there are no checks and balances to effectively limit the "freedom" to be wealthy and the "freedom" to be poor, both the beneficiaries and the victims of the system are (alienated) "forced", as it were, to contribute their quota, in differently - opportune ways, to the crime-problem. And herein lies the "crimogeny of the capitalist system". "It is important to note the interactions between unjustified elite-dominated corruption (including their corrupting consequences) and the justified disposition of street/common/working-class criminals on the one hand and between these and crime-control agencies and personnel (from lawmakers to policemen and other enforcement agencies), themselves either elite, working - class, or commoner, on the other - all within the pressures of the country's capitalist development strategy. These interactions (dictated by the nature of Nigeria's system) would explain most, if not all, the identifying attributes and characteristics of the crime of corruption." 32

Odekunle also agreed with the position of the United Nation's Organisation (UNO) with respect to the consequence of a society built on corruption. According to the UN:

"In identifying the causes of crimes involving the abuse of power, it can be noted that, while these might in some cases involve personal greed or personality defects, in most they are rooted in intimately interlocked social, economic and political conditions which facilitate such criminality ... One facilitating condition is the cultural emphasis on

\footnotetext{
${ }^{32}$ Femi Odekunle, "Controlling Indiscipline and Corruption in Nigeria: Fundamental and Short-term Measures", in Perspectives on Corruption and other Economic Crimes in Nigeria pp. $15-16$.
} 
material success and power as resources of status within a society ... When the legitimate use of power does not provide access to desired material goods and political goals, power may be abused to attain them. Raised expectations ... the spread of the "consumer society", increasing poverty, unemployment and job insecurity, ... strengthen the temptation to use managerial and public position or political opportunity for illicit short-cuts to the "good life" ... Legal conditions can also influence the forms of crime. The level and direction of law -enforcement and regulatory activity may discourage certain kinds of law - breaking while encouraging others. Powerful enterprises often use their power to shape the legal and other environments in which they operate. While the wanton abuse of power by those wielding it is not a rarity, powerful persons or entities more often break societal rules to achieve goals they cannot attain through legitimate means." 33

The perversity of corruption and bad governance red to the termination of the first government that was put in place within the first six years of its existence. When Chuckwuma Kaduna Nzeogwu led the young officers that struck on the $15^{*}$ day of January 1966, no one was left in doubt as to the veracity of their mission. The first broadcast to usher in Military rule in Nigeria made by Chuchwuma Kaduna Nzeogwu summarised the level of bad governance and the phenomenon of corruption that had pervaded the country, six years after its independence. His broadcast was couched in this language:

"The aim of the Revolutionary Council is to establish a strong and prosperous nation, free from corruption and internal strife ... our enemies are the political profiteers, the swindlers, the men in high and low places that seek bribes and demand ten percent; those that seek to keep the country divided permanently so that they can remain in office as ministers or VIPS at least, the tribalists, the nepotists, those that make the country look big for nothing before international circles; those that have corrupted our society and put the Nigeria calendar back by their hands and deeds." 34

The coup of January 1966 led to the unfortunate killing of some distinguished Nigerians. The coup was marred by tribal sentiment and in retaliation against the January 1966 coup, there was a counter-coup in July

\footnotetext{
${ }^{33}$ Odekunle op. cit. pp $16-17$

${ }^{44}$ Adewale Ademoyega: Why we Struck, The story of the First Nigerian Coup pg. 89.
} 
1966. The period between July 1966 and September 1979 marked a long period of military rule. The no-nonsense posture of Murtala Mohammed and Obasanjo led to the great purge and other stern measures they took against the perceived decadence in the society. By the time the civilian

government was put in place in October 1979, corruption had become a national malaise. Part of the reasons for terminating the civilian rule of the Second Republic was corruption and general decadence. So pervading were these societal problems that war against indiscipline was introduced by the duo of Buhari and Idiagbon. Babangida perceived the problem of corruption. Among some measures he took was the setting up of the Eso led National Committee on Corruption and other economic crimes. It is also interesting to note that General Abacha too spoke against corruption. At the inception of the present civilian dispensation came the realisation of the urgent need to put in place a Commission to fight economic crimes. This gave birth to the Independent Corrupt Practices and Other Offences Commission put in place vide the Corrupt Practices and Other Related Offences Act 2000 as amended.

As stated above, corruption has been the bane of our society even after Nzeogwu identified it in 1966. Successive governments tried to tackle this problem as could be seen in the following programmes of successive governments ${ }^{35}$ :

(i) Gowon Administration - The nine-point programme of Gowon and the Public Officers (Investigation of Assets) Decree No. 5 of 1966.

(ii) Murtala/Obasanjo Administration - The Corrupt Practices Decree 1975 and the Anti - Corruption War, Code of Conduct Bureau and a Code of Conduct Tribunal,

(iii) Buhari - Idiagbon Administration War Against Indiscipline,

(iv) Babangida Administration - Setting up of National Committee on Corruption and other Economic Crimes,

(v) Abacha/Abdulsalami Administration Indiscipline, Corrupt Practices and Economic Crime (Prohibition) Decree 1994; Failed Banks (Recovery of Debts) and Financial Malpractices in Banks Decree (No. 18) 1994.

(vi) Obasanjo Civilian Administration - Independent Corrupt Practices and Other Related Offences Commission/The Corrupt Practices and Other Related Offences Act 2000.

Having dealt with the socio-political dimension of corruption in Nigeria and its effect, it is necessary to also put in proper perspective the

\footnotetext{
${ }^{35}$ Ayua I. A., SAN, “Overview of Corruption in Nigeria” in Problems of Corruption in Nigeria op. cit. pp. 20-23.
} 
instruments on corruption that directly touch on governance at a general level.

\section{Legal Instruments Put in Place for the Control of Corruption}

The Criminal Code was put in place as far back as 1945. At the time the Criminal Code was put in place, the problem of corruption has not reached a complex level, as is the position now. Section 98 of the Criminal Code provides for what has been regarded to as official corruption. It provides that:

\section{"Any person who -}

(1) being employed in the public service, and being charged with the performance of any duty by virtue of such employment, not being a duty touching the administration of justice, corruptly asks, receives, or obtains, or agrees or attempts to receive or obtain, any property or benefit of any kind for himself or any other person on account of anything already done or omitted to be done, or to be afterwards done or omitted to be done, by him in the discharge of the duties of his office; or

(2) corruptly gives, confers, or procures, or promises or offers to give or confer, or to procure or attempt to procure, to, upon, or for, any person employed in the public service, or to, upon, or for any other person, any property or benefit, of any such act or omission on the part of the person so employed, is guilty of a felony, and is liable to imprisonment for seven years."

Although section 78 of the Criminal Code is the only section in Chapter XII where the word corruption has been used, many of the sections of that Chapter are branches of the same tree called corruption. These other sections are section 99 (extortion by public officers); section 100 (public officers receiving property to show favour); section 101 (public officers interested in contracts); section 102 (officers charged with administration of property of a special character or with special duties); section 103 (false claims by officials); section 104 (abuse of office); section 105 and (false certificates by public officers).

Indeed, apart from the greater part of Chapter XII which deals with corruption in unmistaken terms, part of Chapter XIII deals with corruption. The relevant sections in this regard include section 112 (bargaining for offices in public service); section 114 (judicial corruption); section 115 
(accepting reward to influence members of native tribunals); section 116 (official corruption not judicial but relating to offences) and section 121 (corruption of witnesses).

With respect to the Penal Code $^{36}$, sections 115, 116, 117, 118 and 121 are relevant.

Section 115 of the Penal Code provides that:

"Whosoever being or expecting to be a public servant accepts or obtains or agrees to accept or attempts to obtain from any person for himself or for any other person, any gratification whatever whether pecuniary or otherwise, other than lawful remuneration, as a motive or reward -

(a) for doing or forbearing to do any official act; or

(b) for showing or forbearing to show in the exercise of his official functions favour or disfavour to any person; or

(c) for rendering or attempting to render any service or disservice to any person with any department of the public service or with any public servant as such, shall be punished -

(i) with imprisonment for a term which may extend to seven years or with fine or with both

(ii) if such public servant is a public servant in the service of the Government of Northern Nigeria or of the Government of the Federation acting in a judicial capacity or carrying out the duties of a police officer, with imprisonment for a term which may extend to fourteen years or with fine or with both."

Section 116 of the Penal Code provides that:

"Whoever accepts or obtains or agrees to accept or attempts to obtain from any person for himself or for any other person any gratification whatever whether pecuniary or otherwise as a motive or reward for inducing by corrupt or illegal means any public servant-

(a) to do or forbear to do any official act; or

(b) in the exercise of the official functions of such public servant to show favour or disfavour to any person; or

(c) to render or attempt to render any service or disservice to any person with any department

\footnotetext{
${ }^{36}$ Cap 96 Laws of the Northern Nigeria.
} 
of the public service or with any public servant as such, shall be punished with imprisonment for a term which may extend to three years or with fine or with both."

Section 117 of the Penal Code deals with abetment by public servant of offence in section 116. It provides that:

"Whoever being a public servant, in respect of whom an offence under section 116 is committed, abets the offence, shall be punished with imprisonment for a term which may extend to three years or with fine or with both."

Section 118 of the Penal Code deals with giving gratification to public servant. It states that:

"Whoever offers or gives or agrees to give any gratification whatever whether pecuniary or otherwise in the circumstances and for any of the purposes mentioned in section 115 and 116 shall be punished with imprisonment which may extend to three years or with fine or with both."

Section 121 of the Penal Code deals with third person'profiting from gratification. It states that:

"Whoever knowingly profits by any gratification or benefit obtained in any of the circumstances mentioned in section 115,116 or 119 but does not take any active part in obtaining such gratification or benefit, shall be punished with imprisonment for a term which may extend to one year or with fine or with both."

One would have thought that a nation with such elaborate provisions in its codes dealing with criminal justice system would not be a corrupt ridden society. The inability to stop corruption and corrupt practices led to various intervening measures for the purpose of eradicating corruption in our society.

\section{Rise of White Collar Crimes}

Subsequent to the enactment of the Criminal and Penal Codes, white-collar crimes became rampant. The Criminal and the Penal Codes in their provisions could not cope with the rise in the white-collar crimes given the methods used and offences that come within the definition of white-collar crimes. What is a white-collar crime? According to Michael Levi ${ }^{37}$, quoting Wheeler, Weisburd and Bode, white-collar crimes, are economic

\footnotetext{
${ }^{37}$ Michael Levi, Regulating Fraud - White-Collar Crime and the Criminal Process, Tavistock Publications, 1987.
} 
offences committed through the use of some combination of fraud, deception or collusion. He continued, such crimes come in many forms:

"they include acts as diverse as the setting up of business to obtain large quantities of goods on credit without intending to pay for them; the use of mail-order businesses to obtain money for goods that one does not intend to supply; the pocketing by brokers or other trustees of funds that they have promised to invest; the diversion of funds to one's own account by means of computers, the illegal use of private inside knowledge to make a profit on share - dealing; and the non-declaration of taxable commercial sales to the tax authorities." ${ }^{38}$

From the list of economic crimes contained in this descriptive definition of it, it would be seen that the Criminal and Penal Codes and the Criminal Procedure Codes are not adequately equipped to deal with the sophistication of economic crimes. The method that has been adopted to combat this problem was the promulgation of specific statutes or Decrees to deal with the all-pervading societal problem of corruption. The Decrees or statutes that have been put in place in this regard include: ${ }^{39}$

(1) Public Officers (Investigation of Assets) Decree Cap. 51966.

(2) Extradition Act 1966

(3) Criminal Justice (Miscellaneous Provisions Act) Cap. 841966.

(4) Extradition Act No. 7 of 1967.

(5) Corrupt Practices Decree No. 38 of 1975.

(6) Constitution of the Federal Republic of Nigeria 1979.

(7) National Drug Law Enforcement Agency Act (Cap. 253) LFN 1990.

(8) Robbery and Firearms (Special Provisions) Act (Cap. 398) LFN 1990.

(9.) Code of Conduct Bureau and Tribunal Act (Cap. 56) LFN 1990.

(10) Companies and Allied Matters Act Cap. 59 LFN 1990.

(11) Evidence Act, Cap 112 LFN 1990.

(12) External Borrowing Act, Cap. 122 LFN 1990

(13) External Loans (Rehabilitation, Reconstruction and Development) Act Cap 123 LFN 1990.

(14) Public Complaints Act Cap 377 LFN 1990.

(15) Police Act Cap 358 LFN 1990.

(16) Public Bodies Act Cap. 37 LFN 1990.

\footnotetext{
${ }^{38}$ At pg. XVIII

39 The summary of these laws has been adopted from the table of statutes in Problems of Corruption in Nigeria rd. Ayua I.A. and Owasanoye B. pp. XII - XX.
} 
(17) Finance (Control and Management)'Act 1990.

(18) Trade Malpractices (Miscellaneous Offences) Decree No. 67 of 1992.

(19) National Agency for Food and Drug Administration and Control (NAFDAC) Decree No. 151993

(20) Indiscipline, Corrupt Practices and Economic Crimes (Prohibition) Decree 1994.

(21) Money Laundering Act (No. 3) of 1995.

(22) Advanced Fee Fraud and Other Related Offences Act Cap. 13 LFN 1995.

(23) Public Enterprises Regulatory Commission Act Cap. 35 LFN 1996.

(24) National Insurance Commission Act 1997

(25) Declaration Against Corruption Act (Business Integrity) 1997.

(26) Constitution of the Federal Republic of Nigeria, 1999.

(27) Counterfeit, Fake Drug and Unwholesome Processed Foods Decree No. 25 of 1999.

(28) Electoral Law of Nigeria, Decree 61999

(29) Investment and Securities Act 1999

(30) Anti-Corruption and Other Related Offences Act Cap 5 LFN 2000.

From the above, it could be said that a lot has been done to combat the phenomenon of corruption but it still remains an unyielding problem in our search for a virile democracy or good governance. The unyielding nature of the problem of corruption especially with respect to public duties by public officials necessitated ${ }^{\wedge}$ fhe promulgation of th\&Anti-Corruption and Other Related Offences Att Cat 5 LFN 2000. This Act will be examined having regard to the nature of its terms of reference, how far it has gone with respect to combating corruption and the legal arguments being put forward with respect to the validity of its existence and the decision that has been reached with respect to the status of this Commission by the Supreme Court of Nigeria.

The Corrupt Practices and Other Related Offences Act, 2002 has 13* June 2000 as its commencement date. Sections 8 - 26 are the relevanl sections with respect to the offences that may be committed under this These offences are:

(i) Gratification by an official; ${ }^{40}$

(ii) Corrupt offers to public officers; ${ }^{41}$

(iii) Corrupt demand by persons; ${ }^{42}$

(iv) Counseling offences relating to corruption; ${ }^{43}$

${ }^{40}$ Section 8

${ }^{41}$ Section 9

${ }^{42}$ Section 10

${ }^{45}$ Section 11 
(v) Fraudulent acquisition of property; ${ }^{44}$

(vi) Fraudulent receipt of property; ${ }^{45}$

(vii) Penalty for offences committed through postal system; ${ }^{46}$

(viii) Deliberate frustration of investigation by the Commission; ${ }^{47}$

(ix) Making false statement or return; ${ }^{48}$

(x) Gratification by and through agents, and definition of agents; ${ }^{49}$

(xi) Bribery of public officer; ${ }^{50}$

(xii) Offence of using office or position for gratification; ${ }^{51}$

(xiii) Penalty for offences under sections $18-19,52$

(xiv) Bribery in relation to auctions; ${ }^{53}$

(xv) Bribery for giving assistance etc in regard to contracts; ${ }^{54}$

(xvi) Duty to report bribery transactions, ${ }^{55}$

(xvii) Dealing with using, holding, receiving or concealing gratification; ${ }^{56}$

(xviii) Making of statement which is false or intended to mislead 57 etc;

(xix) Attempts, preparations, abetments and criminal conspiracies punishable as offence. ${ }^{58}$

A critical look at the offences recognised under this Act will reveal that the offences are not new, what could be said to be new are:

(i) the definition of some of the offences

(ii) the primary responsibility for the prosecution of the cases by the Commission and the court where cases under this Act can be initiated

(iii) distinctive nature of the Commission itself

(iv) power or investigation bestowed on the officers of the commission

(v) power to issue summons against suspects

(vi) special powers have been bestowed on the Chairmen of the Commission.

\footnotetext{
${ }^{44}$ Section 12

${ }^{45}$ Section 13

${ }^{46}$ Section 14

${ }^{47}$ Section 15

${ }^{48}$ Section 16

${ }^{49}$ Section 17

${ }^{50}$ Section 18

51 Section 19

${ }^{52}$ Section 20

53 Section 21

54 Section 22

${ }^{35}$ Section 23

${ }^{56}$ Section 24

${ }^{57}$ Section 25

${ }^{58}$ Section 26
} 
One particular section that has caused some legal argument is section 26(2), which deals with the power of the Attorney General of the Federation to prosecute. It provides that:

"Prosecution for an offence under this Act shall be initiated by the Attorney General of the Federation, or any person or authority to whom he shall delegate his authority, in any superior court of record so designated by the Chief Judge of a state or the Chief Judge of the Federal Capital Territory, Abuja under section 61(3) of this Act; and every prosecution for an offence under this Act or any other law prohibiting bribery, corruption, fraud or any other related offence shall be deemed to be initiated by the Attorney-General of the Federation."

Some states have their respective Criminal Codes for the regulation of criminal activities in these states. Many of the codes contain provisions i dealing with corruption. The Attorney General of the state is deemed to be the Chief Law Officer of each state by virtue of the provisions of the Constitution. ${ }^{59}$ May the Attorney General of the state be hear.d to say that since he is the Chief Law Officer of the state, he must determine whether to prosecute such a case falling within the provision of the Criminal Code of the relevant state. It should be stated that the Attorney General of the Federation has been empowered by virtue of section 174 of the 1999 Constitution with a superior power to prosecute criminal cases. It provides that:

"174(1) The Attorney General of the Federation shall have power -

(a) to institute and undertake criminal proceedings against any person before any court in Nigeria, other than a court - marital, in respect of any offence created by and under any Act of the National Assembly;

(b) to take over and continue any such criminal proceedings that may have been instituted by any other authority or person; and

(c) to discontinue at any stage before judgment is delivered any such criminal proceedings instituted or undertaken by him or any other authority or person."

Furthermore, section 4(3) of the 1999 Constitution provides that "the power of the National Assembly to make laws for the peace, order and good government of the Federation with respect to any matter included in the Exclusive Legislative List shall, save as otherwise provided in this Constitution, be to the exclusion of the House of Assembly of States".

${ }^{59}$ See Section 195 of the 1999 Constitution 
The decision of the Supreme Court in Attorney General of Ondo State vs. The Attorney General of the Federation ${ }^{60}$ has shed more light on this. In this case, the plaintiff on behalf of the government of Ondo State commenced an action under the original jurisdiction of the Supreme Court by originating summons against the Attorney General of the Federation and the Attorneys General of the 35 states comprising the Federal Republic of Nigeria as representatives of the Federal and their State Governments respectively. The plaintiff applied for the determination of the following questions:

(1) Whether the Corrupt Practices and Other Related Offences Act 2000 was a law with respect to a matter or matters upon which the National Assembly was empowered to make laws for the peace, order and good government of Nigeria under the 1999 Constitution of the Federal Republic of Nigeria.

(2) Further and in the alternative to question (1) whether the National Assembly had power to make laws for the peace, order and good government of the Federal Republic of Nigeria with respect to the criminal offences contained in the Corrupt Practices and Other Related Offences Act, 2000.

(3) Whether the Attorney General of the Federation or any person authorised by the Independent Corrupt Practices and Other Related Offences Commission can lawfully initiate, or authorise the initiation of criminal proceedings in any court of law in Ondo State in respect of any of the criminal offences created by any of the provisions of the said Corrupt Practices and Other Related Offences Act, 2000.

(4) Whether all the powers conferred on the Independent Corrupt Practices and Other Related Offences Commission or on the functionaries or agencies of the Federal Government by the Corrupt Practices and Other Related Offences Act, 2000 were exercisable in Ondo State in relation to the activities of any person in that State (including any public officer or functionary or officer or servant of the government of Ondo State).

Uwais CJN who delivered the lead judgment held inter alia: “... Section 4 Subsection (2) of the Constitution provides that the National Assembly has the power to make laws for the peace, order and good government of the Federation with respect to any matter included in the exclusive legislative list. This means that the National Assembly is empowered to legislate under item 60(a) for the purpose of establishing and regulating the ICPC for the Federation. This the National Assembly has

\footnotetext{
${ }^{60}[2002] 6$ SCNJ I
} 
done by enacting the Act. The ICPC is, by the provisions of item 60(a), to promote and enforce the observance of the Fundamental Objectives and Directive Principles of Stale Policy as contained under Chapter II of the Constitution. The question is: now can the ICPC enforce the observance? Is it to use force: is it to legislate or what? The ICPC cannot do either of these because the use of force or coercion in enforcing the observance will require legislation. The ICPC has no power to legislate. Only the National Assembly can legislate... Since the subject of prompting and enforcing the observance comes under the exclusive legislative list it seems to me that the provisions of item 68 of the exclusive legislative list come into play. Therefore, it is incidental or supplementary for the National Assembly to enact the law that will enable ICPC to enforce the observance of the Fundamental Objectives and Directive Principles of the State Policy. Hence the enactment of the Act which contains provisions in respect of both the establishment and regulation of ICPC and the authority for the ICPC to enforce the observance of the provisions of section 15 subsection (5) of the Constitution." 61

One other thing that should be .noted is the provision of section 26 of the Corrupt Practices and Other Related Offences Apt, 2000. This section deals with attempts. Section 26(1 )(b) makes preparation an attempt to commit an offence under the Act. This is contrary to the interpretation of section 4 of the Criminal Code as interpreted in R v. Seidu and R. v. Offiong ${ }^{63}$ where the court held in both cases that because of the inconclusive nature of 'preparation' in the effort or omission to commit an offence, it is unsafe in the area of criminal law of punish for such equivocal act as "preparation".

A bill is now before the National Assembly for the purpose of amending the Corrupt Practices and Other Related Offences Act, 200064. The bill has the effect of changing some sections in the 2000 Act especially with respect to imprisonment. Fines may be imposed instead of imprisonment with respect to the stipulations in some of the sections of the Act. The power of appointment of the Chairman of the Commission may

${ }^{61}$ at pg. 37

${ }^{6}$ [1960JWNLR32

${ }^{63}[\mathrm{I} 936] 3 \mathrm{WACA}^{\wedge} 3$

${ }^{64}$ See The Comet, Sunday February 9,2003. The Bill is titled "The Corrupt Practices and other Related Offences. (Amendment) Bill, 2003. 
now be bestowed on the National Judicial Council subject to confirmation by the Senate. ${ }^{65}$ Having regard to the foregoing discussion with respect to corruption, it may be said that corruption has been the bane of democracy or good governance in Nigeria.

\section{Concluding Remarks}

It is beyond doubt that democracy or good governance is the desire of any country that cherishes fundamental values that deal with freedom, happiness, peace and order in the society. Democracy or good governance assures the possibility of good planning both at private and public levels. Corruption is a social problem. Its prevalence may jeopardise good governance and democratic values and ideals. Corruption is an indicator of fundamental societal debasement. It is also, an indicator of lack of appreciation of fundamental values and ideas, which make a nation progress. The various laws that have been put in place to tackle the problem of corruption are multiple dimensions of solving the problem of corruption depending on the particular variant of it that calls for judicial intervention at a point in time. It would be more effective if these various laws could be harmonised with the aim of confronting the unyielding problem of corruption in all its facets. It is only if this pragmatic approach is adopted that the phenomenon of corruption which has reversed or put at a standstill our aspirations and efforts to progress and achieve the tenets of democracy or good governance will be fully realised.

${ }^{65}$ Olawale Rasheed, "Senate Repeals Anti-graft Law”, Nigerian Tribune, No. 13,059 Thursday 27 February 2003. Pp. $1 \& 2$. 